United States

Department of

Agriculture

Forest Service

Forest SERVIC

Southern

Research Station

Research Paper

SRS-43

\section{Mechanical Removal of Chinese Privet}

John Klepac, Robert B. Rummer, James L. Hanula, and Scott Horn

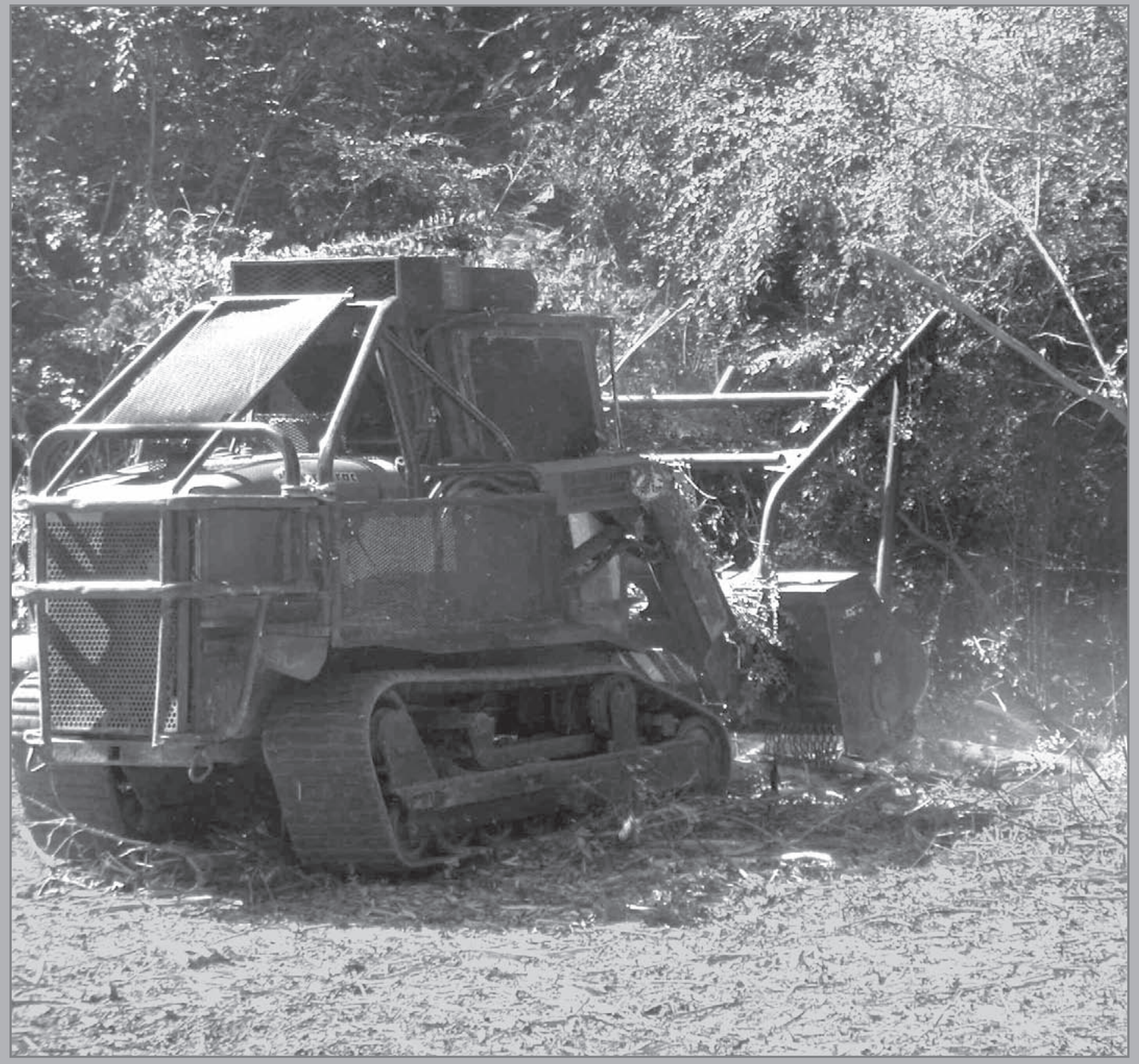




\section{The Authors}

John Klepac, General Engineer, and Robert B. Rummer, Research Engineer, U.S. Department of Agriculture Forest Service, G.W. Andrews Forestry Science Laboratory, Auburn University, AL 36849; and James L. Hanula, Research Entomologist, and Scott Horn, Entomologist, U.S. Department of Agriculture, Forest Service, Forestry Sciences Laboratory, Athens, GA 30602-2044.

Cover Photo: Small tracked machine with horizontal mulching head removing Chinese privet at the Botanical Gardens in Athens, GA, during October 2005.

The use of trade or firm names in this publication is for reader information and does not imply endorsement of any product or service by the U.S. Department of Agriculture or other organizations represented here.

\section{PESTICIDE PRECAUTIONARY STATEMENT}

This publication reports research involving pesticides. It does not contain recommendations for their use, nor does it imply that the uses discussed here have been registered. All uses of pesticides must be registered by appropriate State and/or Federal agencies before they can be recommended.

CAUTION: Pesticides can be injurious to humans, domestic animals, desirable plants, and fish or other wildlife if they are not handled or applied properly. Use all pesticides selectively and carefully. Follow recommended practices for the disposal of surplus pesticides and their containers.

January 2007

Southern Research Station 200 W.T. Weaver Blvd. Asheville, NC 28804 


\section{Mechanical Removal of Chinese Privet}

John Klepac, Robert B. Rummer, James L. Hanula, and Scott Horn 



\section{Contents}

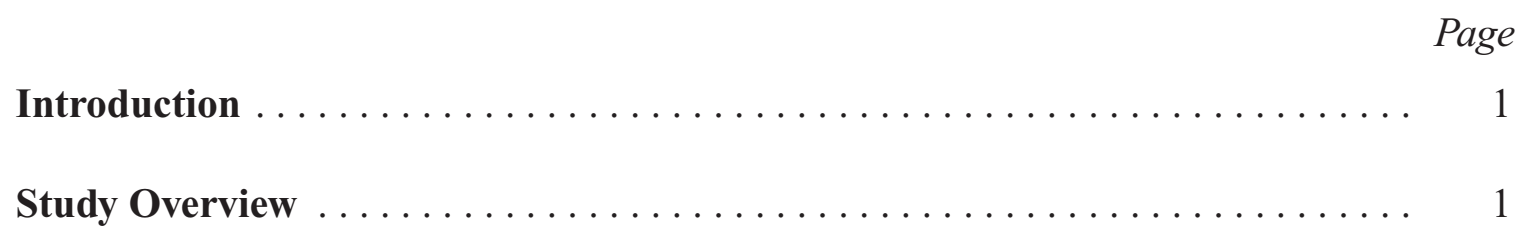

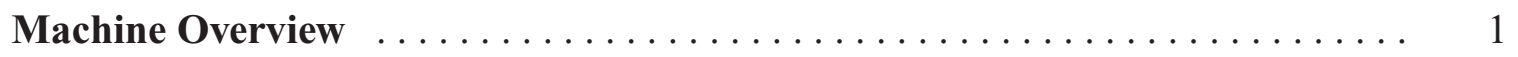

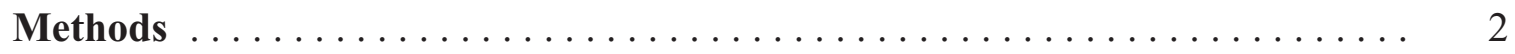

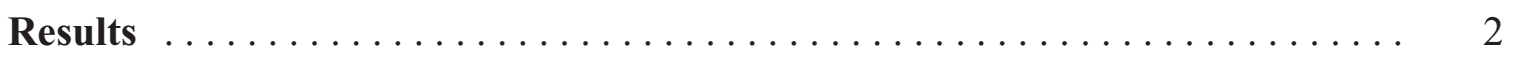

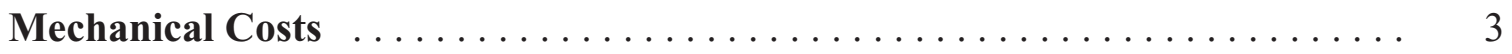

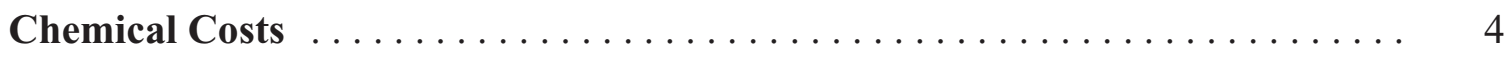

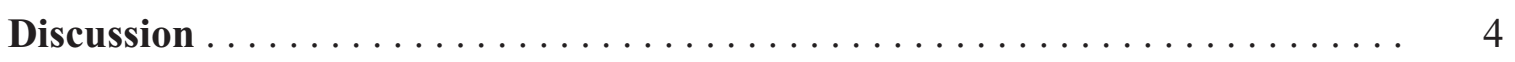

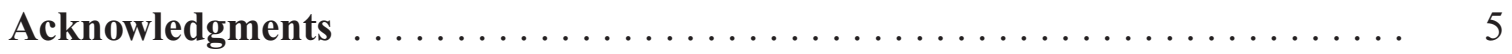

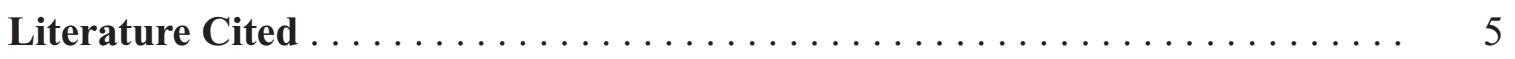





\title{
Mechanical Removal of Chinese Privet
}

\author{
John Klepac, Bob Rummer, Jim Hanula, and Scott Horn
}

\begin{abstract}
Chinese privet (Ligustrum sinense Lour.), a highly invasive nonnative plant, is prevalent in the Southern United States. Chinese privet infestations can hinder regeneration of desirable species, reduce stand productivity, and have other undesirable consequences. A combined mechanical (mulching) and chemical (triclopyr) treatment was applied to Chinese privet in forest stands in Georgia on an experimental basis. The cost of removing Chinese privet was estimated to be $\$ 737$ per acre when a tracked 110-horsepower mulching machine and a two-person herbicide application crew are employed.
\end{abstract}

Keywords: Chemical treatment, Chinese privet, Georgia, invasive nonnative plant, mechanical treatment, mulching machine, triclopyr.

\section{Introduction}

Chinese privet (Ligustrum sinense Lour.) is one of the most invasive nonnative plants in the Southern United States. It infests millions of acres and is extremely difficult to control due to its adaptability to various site conditions (http:// www.gwf.org/vol14no2.htm). Introduced into the United States in the 1800s, it arrived without the natural controls of insects and diseases that keep plants in their natural balance (Miller 1999). Natural regeneration in stands infested with Chinese privet can be adversely affected, resulting in a loss in stand productivity. Miller suggests that invasive exotic plants impede forest productivity, hinder forest-use activities, and limit diversity and wildlife habitat (Miller 1997).

Recommended control measures (Miller 2003) include various applications of herbicide. Control by ground spraying can be very labor intensive, while aerial application can be extremely expensive. In many situations plants are too tall for effective treatment using ground application methods, making it essential to incorporate alternative treatment techniques. For example, injecting herbicide around the trunk into the cambium layer is one alternative but is labor intensive and time consuming. Using a combination of mechanical and chemical treatments to control this invasive species may reduce both labor requirements and treatment costs. Although ineffective by themselves, both mechanical and burning treatments can give additional kill of herbicide-weakened plants and may have a place in an integrated pest management program (Miller 1999).

\section{Study Overview}

This study was initiated by the Insects and Diseases of Southern Forests Research Work Unit of the USDA Forest Service, Southern Research Station. A total of four sites were treated, each measuring 3 to 5 acres and consisting of both bottomland hardwood and mixed pine-hardwood stands. Sites were all located within the floodplain of the Oconee, North Oconee, or Middle Oconee Rivers. The objective was to treat all Chinese privet having a diameter $>1$ inch 1 foot above the ground using a mulching machine. Some privet exceeded 6 inches in diameter at the sites. No other trees with a diameter 4 inches or larger at 4.5 feet aboveground were cut. All preexisting coarse woody debris on the ground $>6$ inches in diameter was avoided, if possible. After mulching, a three-person crew treated cut stumps with a 30-percent mixture of a triclopyr herbicide. The efficacy of the herbicide treatment will be reported in future publications.

Production data were collected on two of the sites - the Sandy Creek Nature Center (site 1) and the Georgia State Botanical Gardens (site 2). Both sites are located in Athens, GA. Site 1 was a bottomland hardwood stand comprised mainly of sweetgum (Liquidambar styraciflua), yellowpoplar (Liriodendron tulipifera), maple (Acer spp.), and elm (Ulmus spp.). Site 1 was flat over most of its area, with abrupt slopes of 12 to 15 percent along approximately half of its perimeter. Site 2 was also a bottomland hardwood stand with boxelder (Acer negundo), sweetgum, river birch (Betula nigra), sycamore (Platanus occidentalis), and pine (Pinus spp.) as the predominant species. Site 2 was flat over its entire area. However, this site did contain a beaver pond which measured approximately 1.65 acres. The pond was totally dry during data collection and no privet was present in this area, but ground conditions were too soft to permit machine operation on the dry pond bottom in any case.

\section{Machine Overview}

The mulching machine used has a 110-horsepower engine and is mounted on 8 -foot-long rubber tracks. It has a low ground pressure (4.2 pounds per square inch) and was appropriate for use in these low areas. The head has a horizontal shaft and 24 flail-type teeth, which rotate at 2,200 
revolutions per minute. Teeth are attached to the head with pins. Tooth life is around 150 hours, while pin life is about 450 hours (Personal communication. 2005. Don Pennington, Contractor, GFA Land Clearing, 1224 Devon Street, SE, Palm Bay, FL 32907). The machine makes a 5.5 -foot swath as it works through an area. The contractor estimated fuel consumption at 6 gallons per hour.

\section{Methods}

Time study data were collected to determine machine productivity in terms of acres per hour. A stopwatch was used to time the machine during operation. Observations of the machine working were taken throughout the day. After timing was completed for an observation, a global positioning system unit was used to determine the size of the treated area. Four observations were collected on site 1 and three on site 2. In addition to time study data, travel speeds were also estimated. For this, the track length was measured to the nearest 0.1 foot using a logger's tape and the machine was timed as the length of the track was traversed.

While the machine progressed through a stand, a threeperson crew followed up the mechanical treatment by applying a 30-percent mixture of the triclopyr herbicide to the exposed cambium of severed stumps using a handheld pressurized chemical sprayer.

\section{Results}

Time study data are provided in table 1 . The mulching machine averaged 0.19 acres per productive machine hour (pmh) overall. Time spent treating 1 acre averaged 6.43 hours for the two sites. Total productive time for site 1 was 11.5 hours. Total area treated was about 2.85 acres, which resulted in a gross productivity of 0.25 acres per pmh. Time study data estimated a productivity of 0.18 acres per pmh for site 1 . For site 2, total treated area was around 3.20 acres. Total machine time for site 2 was 20.5 hours, which gave a gross production rate of 0.16 acres per pmh. A productivity of 0.22 acres per pmh was estimated from the time study data. Figures 1 and 2 illustrate pre- and posttreatment conditions of a bottomland hardwood site infested with Chinese privet.

\section{Table 1-Summary of elementary statistics for time} study

\begin{tabular}{|c|c|c|c|c|}
\hline Variable & Site 1 & Site 2 & Site 1 & Site 2 \\
\hline & \multicolumn{2}{|c|}{ acres/pmh } & \multicolumn{2}{|c|}{ hours/acre } \\
\hline Mean & 0.18 & 0.22 & 6.97 & 5.72 \\
\hline Standard deviation & 0.070 & 0.120 & 4.511 & 3.166 \\
\hline Minimum & 0.07 & 0.11 & 4.58 & 2.88 \\
\hline Maximum & 0.22 & 0.35 & 13.73 & 9.13 \\
\hline
\end{tabular}

$\mathrm{pmh}=$ productive machine hour

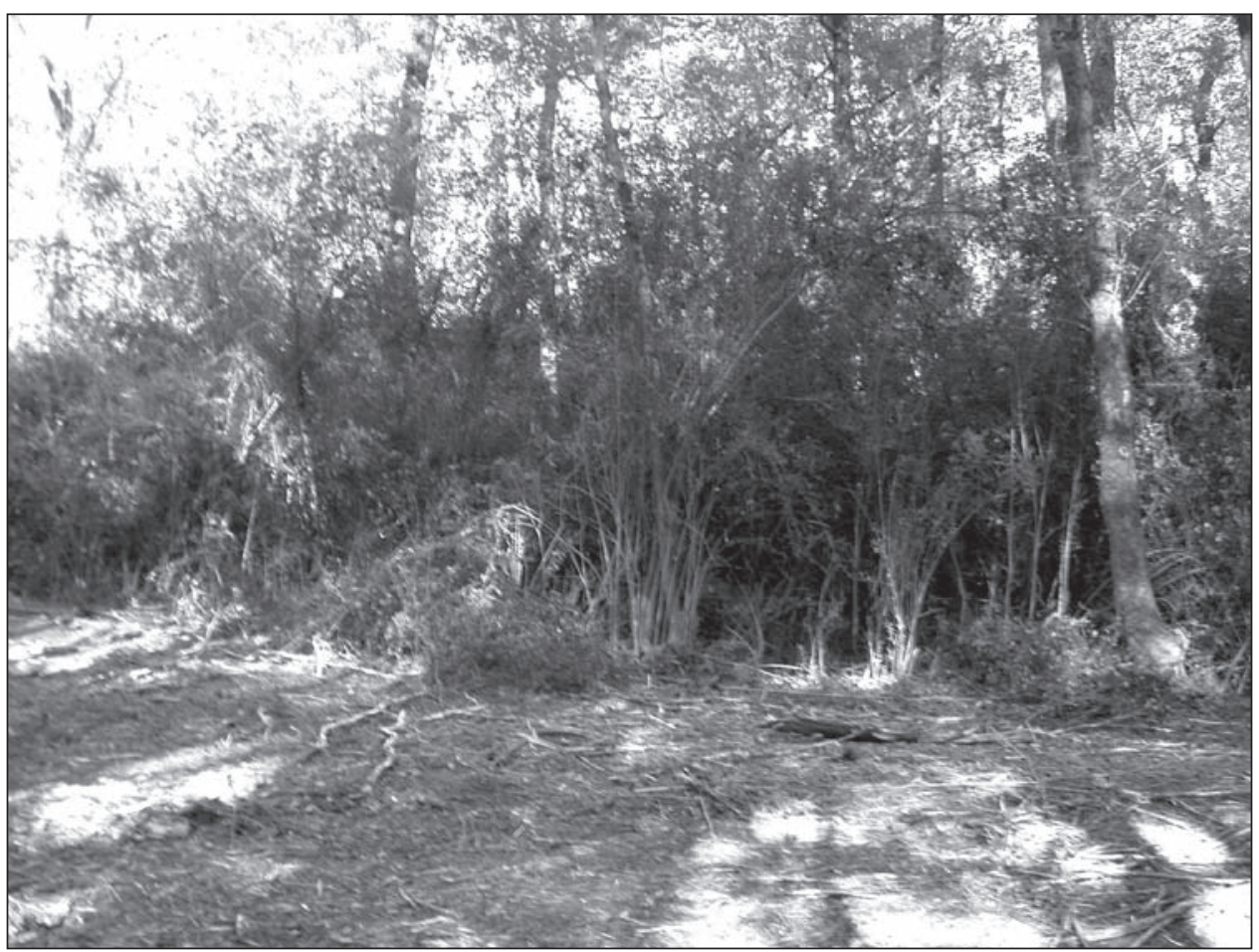

Figure 1-Site 1: Pretreatment. 


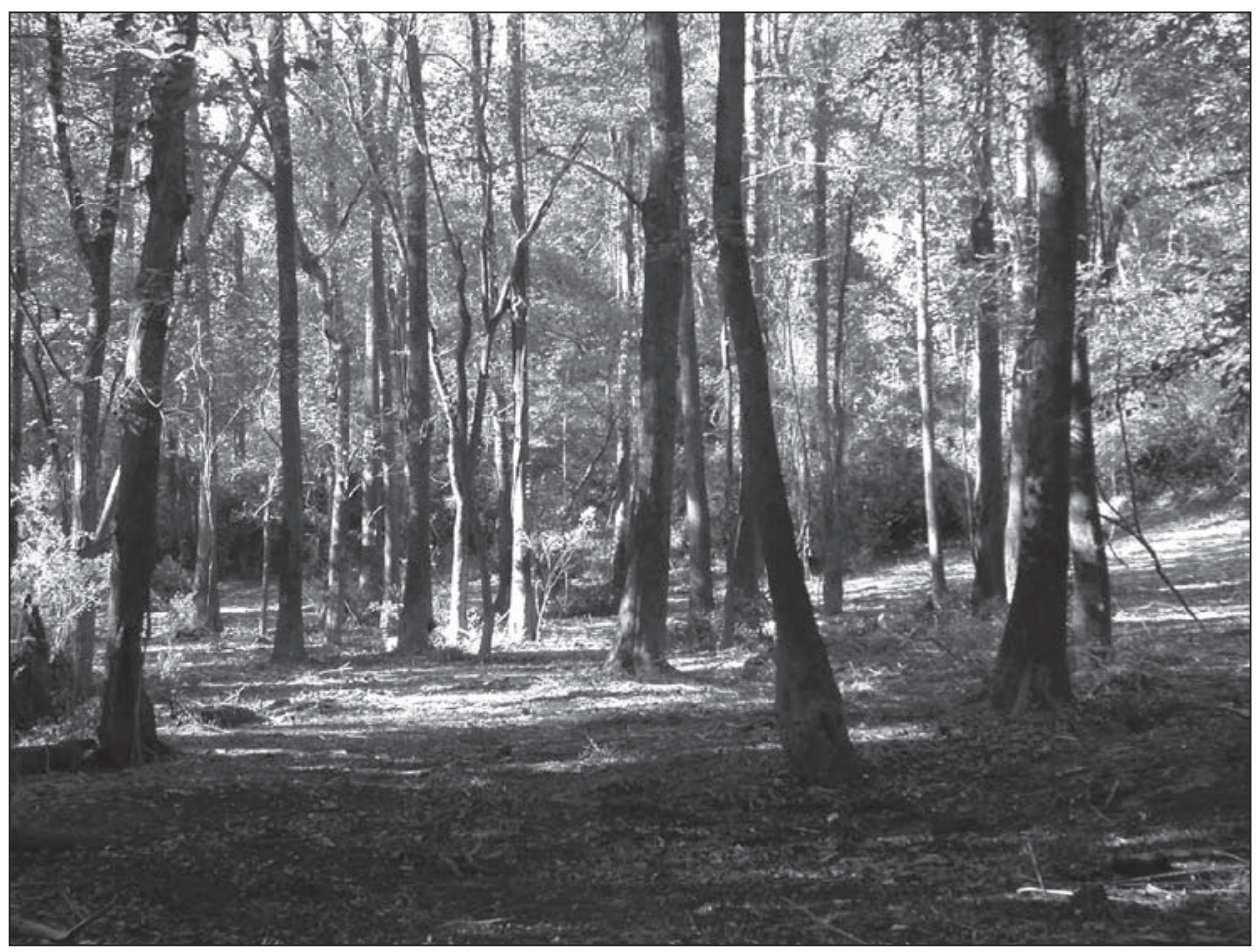

Figure 2-Site 1: Post-treatment.

\section{Mechanical Costs}

Owning and operating costs for the mulching machine were estimated using a machine rate analysis (Miyata 1980) and are summarized in table 2. Salvage value was estimated to be 20 percent of the purchase price (Brinker and others 2002). An interest rate of 10 percent and an insurance rate of 4.5 percent (Brinker and others 2002) of the purchase price were assumed. Fuel cost was calculated using $\$ 2.15$ per gallon for diesel fuel and a fuel consumption rate of 0.0545 gallons per horsepower hour. A rate of 36.8 percent of fuel cost was used to estimate lube cost (Brinker and others 2002). A repair and maintenance rate of 100 percent of annual depreciation was assumed (Brinker and others 2002). Costs for teeth and pins were calculated using figures obtained from talking with the owner. For a forestry heavy equipment operator (occupation code 8160 ), a rate of $\$ 15$ per scheduled machine hour was used, plus 30 percent for benefits. Machine utilization was assumed to be 75 percent.

The estimated total cost of $\$ 71.40$ per scheduled hour includes owning, operating, plus labor and benefits, and 20 percent for profit and overhead. Cost per acre is the ratio of total cost on a pmh basis to a productivity of 0.18 acres per

Table 2-Cost summary for the mulching machine

\begin{tabular}{|c|c|c|c|c|c|}
\hline Variable & Cost & Owning & Operating & Total cost & \$/acre \\
\hline Purchase price $(\$)$ & 110,000 & & & & \\
\hline Salvage value (\$) & 22,000 & & & & \\
\hline Depreciation (\$/yr) & 17,600 & & & & \\
\hline Average yearly investment $(\$ / y r)$ & 74,800 & & & & \\
\hline Interest $(\$ / y r)$ & 7,480 & 14.22 & 25.78 & 71.40 & 529 \\
\hline Insurance (\$/yr) & 3,366 & & & & \\
\hline Fuel and lube $(\$ / \mathrm{pmh})$ & 17.63 & & & & \\
\hline Repair and maintenance $(\$ / \mathrm{pmh})$ & 11.73 & & & & \\
\hline Teeth and pins $(\$ / \mathrm{pmh}$ & 5.01 & & & & \\
\hline Labor and benefits (\$/smh) & 19.50 & & & & \\
\hline
\end{tabular}

$\mathrm{pmh}=$ productive machine hour; $\mathrm{smh}=$ scheduled machine hour 
pmh. These machine costs reflect the average costs over the life of the machine and do not account for taxes.

Figure 3 illustrates the sensitivity of cost per acre to productivity, especially in the range from 0.1 to 0.5 acres per pmh. An increase in productivity from 0.2 acres per pmh to 0.3 acres per pmh results in a 33 -percent reduction in cost per acre. Alternatively, going from 0.9 acres per pmh to 1 acre per pmh results in a 10-percent reduction in cost.

\section{Chemical Costs}

About 6.75 gallons of the herbicide were applied to cut stumps at each site. The market price for this type of herbicide is around $\$ 89$ per gallon. This results in a total chemical cost of approximately $\$ 200$ per acre. To effectively treat freshly cut stumps, the chemical application needs to be concurrent with the mechanical treatment. In this study, a three-person crew followed the machine and sprayed cut stumps. However, a two-person crew seems adequate for this size machine. U.S. Department of Labor wage rates for brush thinners (occupation code 8010) in Georgia are $\$ 11.53$ per hour. With 30 percent benefits the labor cost for a two-person crew would be around $\$ 30$ per hour. If the operation is proceeding at 0.2 acres per hour, the total cost of chemical and labor would be $\$ 350$ per acre. Assuming 20 percent for profit and overhead results in a total chemical and labor cost of $\$ 420$ per acre.

\section{Discussion}

The mulching machine used is small and maneuverable, and maneuverability is an important factor when operating in a residual stand. However, the small size of the machine also resulted in low productivity in terms of acres per hour treated and, thus, higher total treatment costs. It seems unlikely the machine used would be capable of treating more than 0.3 acres per pmh under the conditions observed in this study. At this production rate, mechanical treatment cost would be around $\$ 317$ per acre. Therefore, chemical and manual labor costs for chemical application are an additional $\$ 420$ per acre for a total treatment cost of $\$ 737$ per acre. A larger machine would be more productive, although higher owning and operating costs would also be incurred. For example, one available machine would likely be able to treat at least 0.75 acres per pmh. With a machine price of $\$ 300,000$ mechanical treatment cost would be around $\$ 292$ per acre. A production rate of 1.25 acres per pmh would result in a mechanical cost of $\$ 175$ per acre, which is also possible for the larger size machine.

It is important to recognize that mechanical treatment of privet, by itself, is not a complete tool. Effective herbicide application is required to control sprouting. The combined operational costs measured in this study are about $\$ 700$ per acre with over half associated with the chemical application. However, the mulching machine ground the stumps down to the level of the soil and distributed mulched privet over the entire site. This made finding and treating stumps difficult. Postponing herbicide treatment until stump sprouts appear and then applying foliar herbicide to kill residual privet would reduce costs because a follow-up foliar application will be required to kill seedlings and stumps that were missed. A late fall or early winter foliar application should effectively kill the privet with minimal impact on the native plant community (Harrington and Miller 2005).

Cost curve for the mulching machine used.

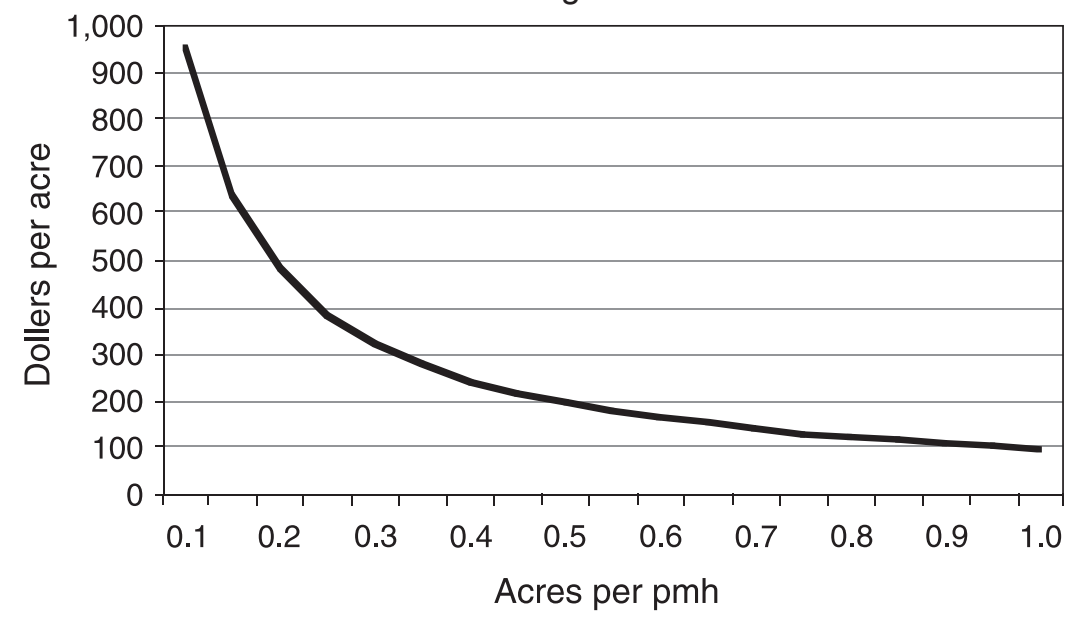

Figure 3-Effect of productivity on cost per acre for the mulching machine used. $\mathrm{pmh}=$ production machine hour. 


\section{Acknowledgments}

Funding for the Chinese privet removal study was provided through the USDA Forest Service, State and Private Forestry, Forest Health Protection, Special Technology Development Grant R8-2005-01. Funding for the production study provided by the USDA Forest Service, Southern Research Station, Forest Operations Research Work Unit.

\section{Literature Cited}

Georgia Wildlife Federation. http://www.gwf.org/vol14no2.htm/. [Date accessed: December 2006].

Harrington, T.; Miller, J.H. 2005. Effects of application rate, timing, and formulation of glyphosate and triclopyr for control of Chinese privet (Ligustrum sinense). Weed Technology. 19: 47-54.

Miller, J.H. 1997. Exotic plants are invading southeastern forests. Alabama Wildlife. Spring/Summer: 36-39.

Miller, J.H. 2003. Nonnative invasive plants of southern forests. Gen. Tech. Rep. GTR-SRS-62. Asheville, NC: U.S. Department of Agriculture Forest Service, Southern Research Station. 93 p.

Miyata, E.S. 1980. Determining fixed and operating costs of logging equipment. Gen. Tech. Rep. NC-55. St. Paul, MN: U.S. Department of Agriculture Forest Service, North Central Research Station. 16 p. 



Klepac, John; Rummer, Robert B.; Hanula, James L.; Horn, Scott. 2007. Mechanical removal of Chinese privet. U.S. Department of Agriculture Forest Service. Res. Pap. SRS-43. Asheville, NC: U.S. Department of Agriculture Forest Service, Southern Research Station. 5 p.

Chinese privet (Ligustrum sinense Lour.), a highly invasive nonnative plant, is prevalent in the Southern United States. Chinese privet infestations can hinder regeneration of desirable species, reduce stand productivity, and have other undesirable consequences. A combined mechanical (mulching) and chemical (triclopyr) treatment was applied to Chinese privet in forest stands in Georgia on an experimental basis. The cost of removing Chinese privet was estimated to be $\$ 737$ per acre when a tracked 110-horsepower mulching machine and a two-person herbicide application crew are employed.

Keywords: Chemical treatment, Chinese privet, Georgia, invasive nonnative plant, mechanical treatment, mulching machine, triclopyr. 


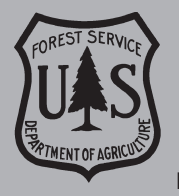

The Forest Service, United States Department of Agriculture (USDA), is dedicated to the principle of multiple use management of the Nation's forest resources for sustained yields of wood, water, forage, wildlife, and recreation. Through forestry research, cooperation with the States and private forest owners, and management of the National Forests and National Grasslands, it strives-as directed by Congress-to provide increasingly greater service to a growing Nation.

The USDA prohibits discrimination in all its programs and activities on the basis of race, color, national origin, age, disability, and where applicable, sex, marital status, familial status, parental status, religion, sexual orientation, genetic information, political beliefs, reprisal, or because all or part of an individual's income is derived from any public assistance program. (Not all prohibited bases apply to all programs.) Persons with disabilities who require alternative means for communication of program information (Braille, large print, audiotape, etc.) should contact USDA's TARGET Center at (202) 7202600 (voice and TDD).

To file a complaint of discrimination, write to USDA, Director, Office of Civil Rights, 1400 Independence Avenue, SW, Washington, D.C. 20250-9410, or call (800) 795-3272 (voice) or (202) 720-6382 ( TDD). USDA is an equal opportunity provider and employer. 